\title{
New records of spiders from pond littorals in the Czech Republic
}

\section{Vlastimil RŮŽIČKA \& Michal HOLEC}

\begin{abstract}
New records of spiders from pond littorals in the Czech Republic. Tmeticus affinis (BLACKWALL, 1855), Tetragnatha shoshone LEVI, 1981, Clubiona juvenis SIMON, 1878, Marpissa Canestrinii NINNI, 1868, and Theridiosoma gemmosum (L. KOCH, 1877) are new records for the Czech Republic. New data about Enoplognatha caricis (FICKERT, 1876), Theridion hemerobium SIMON, 1914, Rugathodes instabilis (O. P. CAMBRIDGE, 1871), Tetragnatha striata L. KOCH, 1862, and Dolomedes plantarius (CLERCK, 1757) are given. The validity of the name Enoplognatha caricis (FICKERT, 1876) is supported.
\end{abstract}

\section{INTRODUCTION}

Various types of wetlands were studied in the Czech Republic: peatbogs (e.g. KŮRKA 1990, 1995), wet meadows (RŮŽIČKA 1987) and pond margins (MILLER \& OBRTEL 1975). We have focused our arachnological investigations on the still overlooked habitat of pond littorals, i.e. plant communities standing permanently in shallow water. We collected the material inside the dense vegetation and on the water-facing side of the vegetation.

The names of localities are given according to the Geographical Lexicon of the Czech Republic (NOVÁKOVÁ 1991). The number of the grid square (BUCHAR 1982) is given in parentheses (the map was published in Arachnologische Mitteilungen by RŮŽIČKA \& HAJER 1996). The nomenclature follows the checklist of the spiders of the Czech Republic (BUCHAR et al. 1995); new records of spiders ofthe Czech Republic, not mentioned by them, are marked by an asterisk ( $\left.{ }^{*}\right)$. The authors' names are abbreviated (VR, MH). 


\section{RECORDS AND DISCUSSION}

\section{Enoplognatha caricis (FICKERT, 1876)}

Steatoda caricis FICKERT, 1876: p. 28-29

Enoplognatha tecta KEYSERLING, 1884: p. 138, Tab. 6, fig. 86

Enoplognatha camtschadalica KULCZYŃSKI, 1885: pp. 28-29; Tab. IX, fig. 9

SIMON (1914): E. caricis, pp. 283-285, fig. 533, p. 306

SCHENKEL (1930): description of a male of E. camtschadalica, pp. 6-9, fig. 3

WIEHLE (1937): E. caricis, pp. 209-210, figs 251-253

LEVI (1957): E. camtschadalica = E. tecta, pp. 10-15, figs 25, 28, 29, 34-37

MILLER (1971): E. caricis, p. 189-190, plate XXXIII, fig. 8 (probably redrawn from WIEHLE, 1937)

MERRETT \& SNAZELL (1975): E. caricis, redescription of the species, pp. 106-109, figs 6-11 WUNDERLICH (1976): $E$. caricis auct., including SIMON, nec FICKERT = E. tecta, pp.

102-103, figs 17-22; the FICKERT's description is considered invalid, the name

E. tecta is recommended

ROBERTS, M. J. (1985): E. tecta, pp. 192-193, fig. 85d

HEIMER \& NENTWIG (1991): E. caricis, pp. 286-287, plate 129, figs 772.3-772.5 (probably at least fig. 772.4 redrawn from WIEHLE, 1937)

PLATNICK (1993): $E$. caricis and E. tecta are considered separate species

KOMPOSCH (1995): E. tecta, p. 730-732, fig. 1

KUPRYJANOVICZ (1997): E. tecta, p. 185-187, figs 3-6

Material: Sedlec (district of Břeclav), Nesyt pond (7266), 2 June 1969, Igt. et coll. P. Kasal; Bulhary (7166), 20 June 1970, 19, Igt. J. Rusek, coll. J. Buchar; Dubá-Nedamov (5453), 28 June 1995, 2 우, Igt. J. Buchar, 1995, 10 , Igt. L. Beran, coll. J. Buchar; Přeseka, Velký Tisý pond (6954), 26 May 1996, 1ठิ , Igt. MH; Stará Hlína, Nový Vdovec pond (6955), 1 June 1996, 1q, Igt. VR, 18 June 1997, 2우, Igt. MH; Lednice, Pastvisko u Lednice Nature Reserve (7166), 30 May 1997, 19, Igt. MH.

Material for comparison: USA, Connecticut, New Canaan Fairfield Co., April 1956, 1ठ, Igt. M. Statham, det. H. Levi; USA, Wisconsin, Vernon County: Timber Cooley, Coon Valley, May 1949, 2우, det. H. Levi, both coll. American Museum of Natural History; USA, Michigan, East Lansing, 30 May 1929, $1 \hat{0}, 10$ July 1955, 1ㅇ, det. H. Levi, both coll. Museum of Comparative Zoology, Harvard University, Cambridge; Russia, Magadan territory, 14우, Igt. et coll. Yu. Marusik.

European specimens were compared with American and Russian ones. We did not find any differences in the structure of the male palpal organs, epigyne and vulva.

American population of $E$. caricis prefer "more or less dry ground on culture influenced places in Newfoundland" (HACKMAN 1954 in LEVI 1957). The populations from East Asia prefer terrestrial and often man made habitats, and the species is very common in the Magadan surroundings 
and on Kurile Islands (MARUSIK in litt.). However, all sites mentioned are not far from the seacoast (and exhibits probably high air humidity). The European populations inhabit exclusively the wetlands (all literature sources cited). We recorded $E$. caricis in littoral stands of the fish ponds, consisting of dense tussocks of sedge grass, especially Carex elata. It builds its little web in the lower part of the tussocks in the space in a leaf bend; not under the overhanging leaves (it is hard to obtain material by beating), not higher up in the tussock (it is hard to obtain the material by sweeping). The material is only obtainable by picking up individuals while wading through high sedge grass growths in the water. M. Holec recorded five females with light yellow brown cocoons during one hour of such examinations.

Zelotes puritanus CHAMBERLIN, 1922 represents a very similar case of different ecological demands in Europe and North America (RŮŽIČKA in press). This species inhabits exclusively original habitats, rocks and rock steppes in Europe, while in North America it inhabits a wider range of habitats. Specimens have been collected in pitfall traps, in aspen, fir, scrub oak, lodgepole and ponderosa pine, and black spruce forests, in beach litter, meadows pastures, prairies, sagebush, and under logs and rocks (PLATNICK \& SHADAB 1983).

FICKERT's description (FICKERT 1876) is clearly insufficient, but this is not an exception among the descriptions from the nineteenth century. E. SIMON must have been in contact with C. FICKERT, he probably saw either a drawing or the actual material. WUNDERLICH (1976) suggested the synonymy: $E$. caricis sensu SIMON = E. tecta. MERRETT \& SNAZELL (1975) verified that the material deposited in SIMON's collection under the label $E$. caricis is the species material mentioned by SIMON under the name "E. caricis (FICKERT)" (SIMON 1914, p. 306). This is the species which presently has been found on several places in Europe and which we try to name properly. It means: $E$. caricis sensu SIMON $=E$. caricis sensu FICKERT. The valid name must be Enoplognatha caricis (FICKERT, 1876).

\section{Theridion hemerobium SIMON, 1914}

Still recorded for Czechia only by KASAL (1982) ( Theridion antusi), BUCHAR (1989) and KÜRKA (1997). In fact, it is quite common in all littoral vegetation, in sedge grass and reed-mace growth. Small wooden foot-bridges passing through littoral growths give good opportunities to collect it. 


\section{Rugathodes instabilis (O. P.-CAMBRIDGE, 1871)}

Up to present time recorded from Czechia only by BUCHAR (1989). For the map of distribution see in RŮŽıČKA (1990). We register more than ten records from all parts of the Czech Republic. Usually collected together with T. hemerobium, but not so abundant.

\section{${ }^{*}$ Tmeticus affinis (BLACKWALL, 1855)}

Material: Stružná, Zelený Rybník pond (5844), 13 June 1997, 3우, Igt. VR, det. Jan Buchar. Water-facing side of dense sedge grass.

\section{*Tetragnatha shoshone LEVI, 1981}

Material: Sedlec (district of Breclav), Nesyt pond (7266), 16 July 1996, 191 juv., Igt. VR, 18

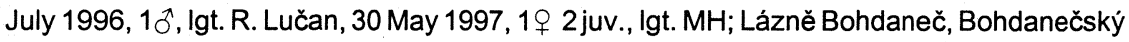
Rybník pond (5960), 24 May 1997, 1 ^ 5우 1 juv., lgt. MH \& VR; Doksy-Břehyně, Břehyňský Rybník pond (5454), 7 June 1997, $1 \hat{\dagger} 2$ 2 9 우 2 juv., Igt. MH; Chabařovice, small water pool (5349), 12 June 1967, 19, Igt. MH.

Reported for Europe for the first time by UHL et al. (1992) from Germany, Hungary and Roumania, then from Austria by KOMPOSCH (1995). We found it mostly on water-facing side of reed vegetation.

\section{Tetragnatha striata L. KOCH, 1862}

Material: Suchdol nad Lužnicí, sand pit (7155), 13 July 1994, 10 1q, Igt. F. Samu, coll. J. Buchar, 5 July 1996, 2우, Igt. VR; Žinkovy, Žinkovský Rybník pond (6546), 23 July 1996, 10 4 우우, Igt. VR; Lednice-Nejdek, small water pool (7166), 16 July 1996, 2 juv., Igt. VR; Střibřec, Novořecké Močály marshes, water pools in inundation area of Nová Řeka channel

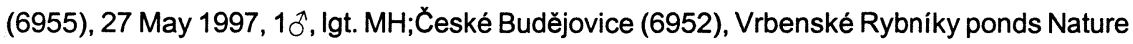
Reserve, 17. June 1997, 10, Igt. MH; Stará Hlína, Nový Vdovec pond (6955), 28 June 1997, 1 , Igt. $\mathrm{MH}$.

On water-facing side of reed and reed-mace vegetation.

\section{Dolomedes plantarius (CLERCK, 1757)}

Material: Lomnice nad Lužnici-Lužnice, Potěšil pond (6954), 5-21 May 1978, 1 đิ, Igt. VR (DUFFEY 1995); Stará Hlína, Nový Vdovec pond (6955), 26 May-13 June 1996, $160^{\lambda} o^{\lambda} 3 q$, Igt. MH; Přeseka, Velký Tisý pond (6954), 1 June 1996, 1 б, Igt. MH; Stríbřec, Novořecké Močály marshes (6955), 27 May-1 June 1997, 2 우, Igt. MH; Hradčany, Hradčanský Rybník

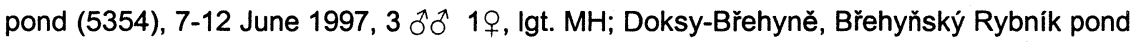
(5454), 7 June 1997, 1ㅇ, Igt. MH.

Prevailing part of the material was obtained by use of floating desk traps (RUீŽIČKA 1982) among sedge grass, and also on floating leaves of yellow water lilies (Nuphar luteum). 
${ }^{*}$ Clubiona juvenis SIMON, 1878

Material: Sedlec (district of Břeclav) (7266), Nesyt pond, 16 July 1996, 3qq, Igt. VR, 30 May 1997, 1 đ 3q +1 juv., Igt. MH; Doksy-Břehyně (5454), Břehyňský Rybník pond, 7 June 1997, 19 , Igt. $\mathrm{MH}$.

On water-facing side of reed vegetation.

NEMENZ (1967)presented continuous distribution of this species in western Europe, and isolated records in Austria and in Roumania.

\section{*Marpissa canestrinii NINNI, 1868}

Material: Lednice (7166), Pastvisko u Lednice Nature Reserve, 30 May 1997, 19, Igt. MH. In rich growth consisting from sedge grass and reed mace.

NEMENZ (1967) composed the map of distribution of this mediterranean species. The occurrence near Lednice represents the most northern record in Central Europe.

\section{*Theridiosoma gemmosum (L. KOCH, 1877)}

We register more than 15 records from all parts of the Czech Republic. It makes its webs above the water surface in various types of marshy vegetation, such as reed and sedge grass growth, it is also abundant under overhanging grass on the bank of channels.

\section{CONCLUSIONS}

Pond littorals host a specific spider assemblage. According to the unaccessibility of this habitat, some of its inhabitants are considered to be rare. We documented, that Theridion hemerobium and Theridiosoma gemmosum, for example, are quite widespread in the Czech Republic. Some species, widespread in humid maritime climates, can exhibit narrower niches in continental climates in Central Europe, where they inhabit exclusively the most humid habitats in pond littorals; this is the case in Rugathodes instabilis, Dolomedes plantarius and Clubiona juvenis.

ACKNOWLEDGEMENT: We are indebted to Prof. H. LEVI, Prof. N. PLATNICK, Dr. Yu. MARUSIK, Prof. J. BUCHAR, and Dr. P. KASALfor kind lown of material, Dr. K. THALER and Dr. R. SNAZELL for usefull discussion about the problem of E. caricis, Dr. M. WOŻNY and Dr. F. ZBYTEK for their help with terrain investigations. 


\section{REFERENCES}

BUCHAR, J. (1982): Publication of faunistic data from Czechoslovakia. - Věst. čs. Společ. zool. 46: 317-318 (in Czech, English summary)

BUCHAR, J. (1989):The knowledge of the present Bohemian arachnofauna and its improvement to evaluation of natural conditions. Thesis, Charles University, Praha, 206 pp. (in Czech)

BUCHAR, J., RŮŽIČKA, V. \& A. KŮRKA (1995): Check list of spiders of the Czech Republic. In: V. RỦŽIČKA (ed.): Proceedings of the 15th European Colloquium of Arachnology. Institute of Entomology, České Budějovice. S. 35-53

DUFFEY, E. (1995): The distribution, status and habitats of Dolomedes fimbriatus (CLERCK) and D. plantarius (CLERCK) in Europe. In: V. RỦŽIČKA (ed.): Proceedings of the 15th European Colloquium of Arachnology. Institute of Entomology, České Budějovice. S. 54-65

FICKERT, C. (1876): Verzeichnis der schlesischen Spinnen. - Z. Ent. (NF) 5: 46-76

HEIMER, S. \& W. NENTWIG (1991): Spinnen Mitteleuropas. Verlag Paul Parey, Berlin und Hamburg, $543 \mathrm{pp}$.

KASAL, P. (1982): Theridion antusi sp. n. and Mysmena jobi from Czechoslovakia (Araneida, Theridiidae and Symphytognathidae). - Acta Entomol. Bohemoslov. 79: 73-76

KOMPOSCH, CH. (1995): Enoplognatha tecta (KEYSERLING) und Tetragnatha shoshone LEVI neu für Österreich (Araneae: Theridiidae, Tetragnathidae). - Carinthia II 185/105: 729-734

KUPRYJANOWICZ, J. (1997): Spiders of the Biebrza National Park - species new and rare to Poland. In: M. ZABKA (ed.): Proceedings of the 16th European Colloquium of Arachnology. Wyższa Szkoła Rolniczo-Pedagogiczna, Siedlce. S. 183-194

KÜRKA, A. (1990): The arachnofauna of Bohemian peat bogs. Spiders (Araneida) of the State Nature Reserve Mrtvý Luh, Sumava Mts. - Acta Mus. Nat. Pragae, Ser. B 46: 37-77

KŮRKA, A. (1995): Some rare and remarkable spider species (Araneida) from peatbogs of the Czech Republic. - Čas. Nár. Muz., Řada prírodověd. 164: 77-86

KŮRKA, A. (1997): The spider fauna (Araneida) of the military area Ralsko. - Bezděz 5: 237-268 (in Czech, English and German summary)

LEVI, H. W. (1957): The spider genera Enoplognatha, Theridion, and Paidisca in America north of Mexico (Araneae, Theridiidae). - Bull. amer. Mus. nat. Hist. 112 (1): 1-123

MERRETT, P. \& R. G. SNAZELL (1975): New and rare British Spiders. - Bull. Brit. Arach. Soc. 3: $106-112$

MILLER, F. (1971): Order Spiders-Araneida. In: M. Daniel \& V. Černý (eds), Klič zviřeny ČSSR IV [Key to the fauna of the Czechoslovakia IV].ČSAV, Praha. S. 51-306 (in Czech)

MILLER, F. \& R. OBRTEL 1975: Soil surface spiders (Araneidea) in terrestrial reed swamp in southern Moravia (Czechoslovakia). - Acta Entomol. Bohemoslov. 72: 272-285

NEMENZ, H. (1967): Einige interessante Spinnenfunde aus dem Neusiedlerseegebiet. - Anz. Österr. Akad. Wiss., math.-naturw. Kl. 1967: 132-139

NOVÁKOVÁ, B. (ed.) (1991): Obce a sidla [The settlements of the Czech Republic]. Academia, Praha, 1-604 (I), 605-1227 (II) (in Czech)

PLATNICK, N. I. (1993): Advances in spider taxonomy 1988-1991. With synonymies and transfers 1940-1980. New York Entomological Society \& American Museum of Natural History, 846 pp. 
PLATNICK, N. I. \& M. U. SHADAB (1983): A revision of the American spiders of the genus Zelotes (Araneae, Gnaphosidae). Bull. Amer. Mus. Nat. Hist. 174: 97-192

ROBERTS, M. J. (1985): The spiders of Great Britain and Ireland. Volume I. Harley Books, Colchester, $229 \mathrm{pp}$.

RŮŽIČKA, V. (1982): Modifications to improve the efficiency of pitfall traps. - Newsl. Br. arachnol. Soc. 34: 2-4

RŮŽIČKA, V. (1987): An analysis of spider communities in the meadows of the Treboň basin. - Acta Sc. Nat. Brno 21 (5): 1-39

RŮŽlČKA, V. (1990): On the lithobionts Lepthyphantes notabilis, Rugathodes bellicosus and on Rugathodes instabilis (Araneae: Linyphiidae, Theridiidae). - Acta Entomol. Bohemoslov. 86 [1989]: 432-441.

RŮŽIČKA, V. (in press): Spiders in rocky habitats in Central Bohemia. - J. Arachnol.

RỦŽlČKA, V. \& J. HAJER (1996): Spiders (Araneae) of stony debris in North Bohemia. - Arachnol. Mitt. 12: 46-56

SCHENKEL, E. (1930): Die Araneiden der schwedischen Kamtschatka-Expedition 1920-1922. - Ark. Zool. 21A (15): 1-33

SIMON, E. (1914): Les Arachnides de France 6 (1), Paris, Roret. 308 S.

UHL, G., P. SACHER, I. WEISS \& O. KRAUS (1992): Europäische Vorkommen von Tetragnatha shoshone (Arachnida, Araneae, Tetragnathidae). - Verh. naturwiss. Ver. Hamburg (NF) 33: 247-261

WIEHLE, H. (1937): 26. Familie: Theridiidae oder Haubennetzspinnen (Kugelspinnen). In: Dahl M. \& H. Bischoff (eds): Die Tierwelt Deutschlands und der angrenzenden Meeresteile nach ihren Merkmalen und nach ihrer Lebensweise. 33. Teil, Spinnentiere oder Arachnoidea. VIII: Gnaphosidae, Anyphaenidae, Clubionidae, Hahniidae, Argyronetidae, Theridiidae. Verlag von Gustav Fischer, Jena. S. 119-222.

WUNDERLICH, J. (1976): Zur Kenntnis der mitteleuropäischen Arten der Gattungen Enoplognatha Pavesi und Robertus O. Pick.-Cambridge (Araneida: Therididae). - Senckenbergiana biol. 57 (1/3): $97-112$

Vlastimil RŮŽıČKA, Institute of Entomology, Czech Academy of Sciences, Branišovská 31, CZ-370 05 České Budějovice, Czech Republic Michal HOLEC, Biological Faculty, South Bohemian University, Branišovská 31, CZ-370 05 České Budějovice, Czech Republic 